\section{'Tsolakeiko': A Greek Sweet Cherry Cultivar}

\author{
Konstantinos Kazantzis and Thomas Sotiropoulos ${ }^{1}$ \\ Department of Deciduous Fruit Growing in Naoussa, Hellenic Agricultural \\ Organization 'Demeter', Institute of Plant Breeding and Phytogenetic \\ Resources, 59035 Naoussa, Greece
}

\section{Simeon Marnasidis \\ Regional Unit of Pella, Administration of Rural Economy \& Veterinary, 58200 Edessa, Greece}

\section{Ioannis Ganopoulos, Aliki Xanthopoulou, and Panagiotis Madesis Institute of Applied Biosciences, CERTH, Thessaloniki 57001, Greece}

Additional index words. cultivar description, fruit breeding, Prunus avium, self-fertility, $S$-RNase alleles
'Tsolakeiko' is a local Greek cherry cultivar. Productivity and mean fruit weight of 'Tsolakeiko' were significantly higher than 'Bigarreau Burlat' and 'Tragana Edessis'. Total soluble solids of 'Tsolakeiko' were lower than 'Tragana Edessis' but wasn't significantly different from 'Bigarreau Burlat'. Fruits of 'Tsolakeiko' mature $5 \mathrm{~d}$ later than 'Bigarreau Burlat'. The fruits of 'Tsolakeiko' are symmetrical, heartshaped and of mahogany color. Fruits of 'Tsolakeiko' are juicy, sour-sweet when mature, and have a good eating quality. S-RNase alleles determined by PCR fragment analysis of the cultivar 'Tsolakeiko' were $\mathrm{S}_{4} \mathrm{~S}_{4}$ (self fertile and a universal donor). In conclusion, 'Tsolakeiko' is an early promising sweet cherry cultivar due to its quality characteristics.

\section{Origin}

The genotype 'Tsolakeiko' was first observed during the $80 \mathrm{~s}$ in a private orchard owned by Mr. Christos Tsolakis, at the area of Loutraki Arideas (northern Greece, long. $21^{\circ} 94^{\prime} 59^{\prime \prime} \mathrm{E}$; lat. $40^{\circ} 97^{\prime} 11^{\prime \prime} \mathrm{N}$; elevation $350 \mathrm{~m}$ ). This study took place in a commercial orchard at that area. The soil of the experimental orchard at a depth of 0 to $30 \mathrm{~cm}$ was characterized as a clay loam, neutral $(\mathrm{pH}$ 6.5 ), and with low electrical conductivity $\left(0.748 \mathrm{mS} \cdot \mathrm{cm}^{-1}\right)$ and low organic matter $(1.83 \%)$ content. The average maximum temperature from May to August for the years 2011, 2012, 2013, and 2014 was 28.03, 29.78, 31.35, and $30.25^{\circ} \mathrm{C}$, respectively. The mean precipitation in May for the years 2011, 2012, 2013, and 2014 was 92.5, 113 , 54, and $40.5 \mathrm{~mm}$, respectively. The cultivar was a budding from the wild cherry rootstock, which was grafted with the cultivar 'Tragana Edessis' scion. It should be noted at

Received for publication 4 Aug. 2015. Accepted for publication 25 Aug. 2015.

${ }^{1}$ Corresponding author. E-mail: thosotir@otenet.gr. this point that it is a normal practice in mountainous "Almopia" area to allow budding from the wild cherry rootstock to aid the pollination of the cultivars in the orchard as wild cherry is a very good pollinator of all cherry cultivars when they blossom at the same period. It was observed that such a budding produced fruits of superior quality than the cultivar 'Tragana Edessis' (which was the scion variety). For this reason, the owner of the orchard Mr. Tsolakis took care to maintain, propagate, and cultivate the "new" cultivar. Since this new cultivar was proved to be successful as a commercial cultivar as it matured when no other remarkable cultivar was present in the market at that period, it spread quickly in the region and acquired a distinct name and place in the market.
The experimental trees were 12 years old, grafted on wild cherry seedling rootstock (mazzard), trained as a typical vase shape, and planted at a distance of $6 \times 6 \mathrm{~m}$ apart. Productivity data of 4 years (2011-14) reported are means of 25 trees (five replications $\times$ five trees) per cultivar (means were based on data collected from when the trees were 12 years old to when they were 15 years of age), analyzed as a randomized complete block design. Trees were irrigated by means of microsprinklers. Application of nutrients was based on leaf and soil analyses data.

All other fruit characteristics reported were recorded in a random sample of 300 fruits harvested from the experimental trees in each year. Total soluble solids were measured by an Atago 8469 electronic refractometer (Atago Co. Ltd., Tokyo, Japan). Titratable acidity was measured by titration with $0.1 \mathrm{M} \mathrm{NaOH}$, firmness with an Effegi penetrometer equipped with 6-mm tip (Effegi, Milan, Italy), and fruit color with the Minolta CR-300 chromatometer (Minolta, Ahrensburg, Germany) as reported by Kafkaletou et al. (2015) and Chatzicharissis et al. (2011). Leaf botanical characteristics reported were based on a random sample of 100 leaves selected from each experimental tree in each year. Furthermore, dates of anthesis, harvest period, and leaf shedding of the trees were reported.

Consensus primer pairs (PaConsI and PaConsII) developed by Sonneveld et al. (2003) were used to amplify introns I and II of the $S$-RNase gene. Microsatellite genotyping using high resolution melting (HRM) analysis was performed as described by Ganopoulos et al. (2011).
Table 1. Mean yield, fruit weight, total soluble solids, and acidity of the cultivars Bigarreau Burlat, Tsolakeiko, and Tragana Edessis during a period of 4 years.

\begin{tabular}{lcccc}
\hline Cultivar & $\begin{array}{c}\text { Total yield } \\
\left(\mathrm{kg} \cdot \mathrm{ha}^{-1}\right)\end{array}$ & Fruit wt $(\mathrm{g})$ & $\begin{array}{c}\text { Total soluble } \\
\text { solids }(\% \text { Brix })\end{array}$ & $\begin{array}{c}\text { Acidity } \\
(\text { malic acid \%) }\end{array}$ \\
\hline Bigarreau Burlat & $26,600 \mathrm{c}^{\mathrm{z}}$ & $8.0 \mathrm{~b}$ & $13.7 \mathrm{~b}$ & $3.8 \mathrm{c}$ \\
Tsolakeiko & $32,200 \mathrm{a}$ & $10.4 \mathrm{a}$ & $15.1 \mathrm{~b}$ & $5.2 \mathrm{~b}$ \\
Tragana Edessis & $28,800 \mathrm{~b}$ & $7.7 \mathrm{~b}$ & $18.2 \mathrm{a}$ & $7.1 \mathrm{a}$ \\
\hline
\end{tabular}

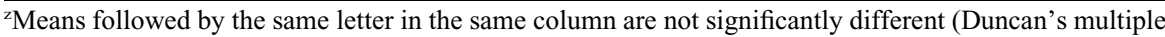
range test; $P<0.05)$.

Table 2. Data of anthesis, maturation, and leaf shedding periods of the cultivars Bigarreau Burlat, Tsolakeiko, and Tragana Edessis during a period of 4 years.

\begin{tabular}{|c|c|c|c|c|c|c|c|}
\hline \multirow[b]{2}{*}{$\mathrm{Yr}$} & \multirow[b]{2}{*}{ Cultivar } & \multicolumn{3}{|c|}{ Anthesis } & \multirow{2}{*}{$\begin{array}{c}\text { Maturation } \\
\text { Full }\end{array}$} & \multicolumn{2}{|c|}{ Leaf shedding } \\
\hline & & Beginning $^{z}$ & Full $^{\mathrm{y}}$ & $\overline{\text { End }}$ & & Beginning & End \\
\hline \multirow[t]{3}{*}{2011} & Bigarreau Burlat & $20 / 3$ & $24 / 3$ & $30 / 3$ & $20 / 5$ & $28 / 10$ & $\overline{18 / 11}$ \\
\hline & Tsolakeiko & $24 / 3$ & $30 / 3$ & $4 / 4$ & $25 / 5$ & $28 / 10$ & $18 / 11$ \\
\hline & Tragana Edessis & $2 / 4$ & $7 / 4$ & $12 / 4$ & $2 / 6$ & $31 / 10$ & $23 / 11$ \\
\hline \multirow[t]{3}{*}{2012} & Bigarreau Burlat & $18 / 3$ & $21 / 3$ & $27 / 3$ & $18 / 5$ & $25 / 10$ & $14 / 11$ \\
\hline & Tsolakeiko & $21 / 3$ & $27 / 3$ & $1 / 4$ & $22 / 5$ & $26 / 10$ & $13 / 11$ \\
\hline & Tragana Edessis & $31 / 3$ & $4 / 4$ & $10 / 4$ & $31 / 5$ & $28 / 10$ & $19 / 11$ \\
\hline \multirow[t]{3}{*}{2013} & Bigarreau Burlat & $23 / 3$ & $28 / 3$ & $2 / 4$ & $23 / 5$ & $30 / 10$ & $21 / 11$ \\
\hline & Tsolakeiko & $27 / 3$ & $2 / 4$ & $7 / 4$ & $27 / 5$ & $31 / 10$ & $23 / 11$ \\
\hline & Tragana Edessis & $5 / 4$ & $9 / 4$ & $15 / 4$ & $3 / 6$ & $2 / 11$ & $25 / 11$ \\
\hline \multirow[t]{3}{*}{2014} & Bigarreau Burlat & $19 / 3$ & $23 / 3$ & $31 / 3$ & $21 / 5$ & $27 / 10$ & $16 / 11$ \\
\hline & Tsolakeiko & $25 / 3$ & $31 / 3$ & $3 / 4$ & $26 / 5$ & $27 / 10$ & $16 / 11$ \\
\hline & Tragana Edessis & $3 / 4$ & $5 / 4$ & $13 / 4$ & $4 / 6$ & $1 / 11$ & $24 / 11$ \\
\hline
\end{tabular}

${ }^{\mathrm{z}} 10 \%$ anthesis.

${ }^{\mathrm{y}} 80 \%$ anthesis. 
The significance of the differences between means was evaluated using Duncan's multiple range test analysis of variance at $P<$ 0.05 carried out in SPSS Version 17 (SPSS Inc., Chicago, IL).

Total yield and mean fruit weight of 'Tsolakeiko' were significantly higher than 'Bigarreau Burlat' and 'Tragana Edessis' (Table 1). Total soluble solids of 'Tsolakeiko' were lower than 'Tragana Edessis' but were not significantly different from 'Bigarreau Burlat'. Acidity of 'Tsolakeiko' was lower than 'Tragana Edessis' but higher than 'Bigarreau Burlat' (Table 1).

Trees of 'Tsolakeiko' are semivigorous with a semiupright growth habit. One-yearold shoots are very vigorous, especially on young trees. Trees become productive from the third year, especially when grafted on dwarfing rootstocks.

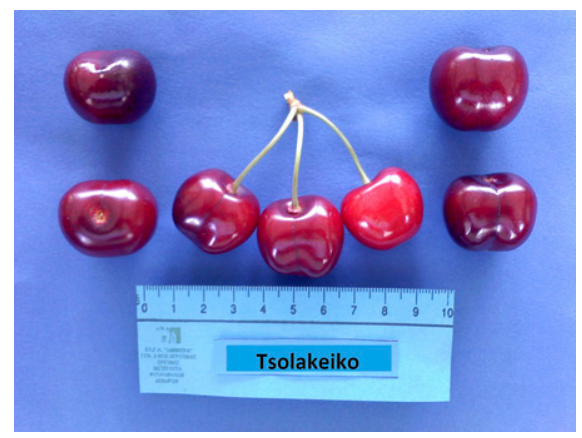

Fig. 1. Fruit of 'Tsolakeiko'.

Table 3. Fruit color parameters of the cultivars Bigarreau Burlat, Tsolakeiko, and Tragana Edessis during a period of 4 years.

\begin{tabular}{lccc}
\hline Cultivar & $L$ & $a$ & Chroma \\
\hline Bigarreau Burlat & $31.21 \mathrm{a}^{z}$ & $26.05 \mathrm{a}$ & $28.14 \mathrm{a}$ \\
Tsolakeiko & $31.59 \mathrm{a}$ & $26.11 \mathrm{a}$ & $27.12 \mathrm{a}$ \\
Tragana Edessis & $30.98 \mathrm{a}$ & $26.48 \mathrm{a}$ & $28.29 \mathrm{a}$ \\
\hline
\end{tabular}

${ }^{\mathrm{z}}$ Means followed by the same letter in the same column are not significantly different (Duncan's multiple range test; $P<0.05$ ).

Table 4. Cracking classification, fruit firmness, fruit length, and fruit width of the cultivars Bigarreau Burlat, Tsolakeiko, and Tragana Edessis during a period of 4 years.

\begin{tabular}{lcccc}
\hline Cultivar & $\begin{array}{c}\text { Cracking } \\
\text { classification }\end{array}$ & $\begin{array}{c}\text { Fruit firmness } \\
\left(\mathrm{kg} \cdot \mathrm{cm}^{-2}\right)\end{array}$ & $\begin{array}{c}\text { Fruit } \\
\text { length }(\mathrm{mm})\end{array}$ & $\begin{array}{c}\text { Fruit } \\
\text { width }(\mathrm{mm})\end{array}$ \\
\hline Bigarreau Burlat & $49 \mathrm{~b}^{\mathrm{y}}$ & $0.66 \mathrm{~b}$ & $22.00 \mathrm{ab}$ & $26.50 \mathrm{a}$ \\
Tsolakeiko & $94 \mathrm{a}$ & $0.79 \mathrm{ab}$ & $25.10 \mathrm{a}$ & $27.70 \mathrm{a}$ \\
Tragana Edessis & $55 \mathrm{~b}$ & $0.89 \mathrm{a}$ & $19.90 \mathrm{~b}$ & $24.70 \mathrm{a}$ \\
\hline
\end{tabular}

${ }^{\mathrm{z}} 0$ : very resistant, 100 : very sensitive.

${ }^{y}$ Means followed by the same letter in the same column are not significantly different (Duncan's multiple range test; $P<0.05)$. without an economic importance. Stone shape of 'Tsolakeiko' is ovoid. The ratio of stone weight to fruit weight is $1 / 22.1$, whereas stone size to fruit size is $1 / 18.9$. The ratios of stone weight to fruit weight of the cultivars 'Bigarreau Burlat' and 'Tragana Edessis' are 1/10.7 and 1/19.25, respectively.

The leaves are large, elliptical in shape, and have dentate margins. Blade length to width ratio is $1 / 0.37$. The petiole is relatively short $(3.6 \mathrm{~cm})$ and thick $(0.18 \mathrm{~cm})$. The nectaries are usually two, kidney shaped and orange-red in color. The ratio of petiole to blade is $1 / 4.97$. Leaf fall of 'Tsolakeiko' starts at Oct. 10 and ends at Nov. 18 (Table 2).

In conclusion, 'Tsolakeiko' is a precocious, promising sweet cherry cultivar due to its quality characteristics. Fruits are large (for the period of harvesting), juicy, sour-sweet when mature, and have a good eating quality. Furthermore, it is a self-fertile cultivar and a universal donor for pollination.

\section{Availability}

'Tsolakeiko' sweet cherry has not registered yet in the official list of the Greek Ministry of Rural Development and Food. Propagation wood is available from the Institute of Plant Breeding and Phytogenetic Resources, Department of Deciduous Fruit Growing in Naoussa.

\section{Literature Cited}

Bekefi, Z. 2006. Review of sweet and sour cherry incompatibility. Intl. J. Hort. Sci. 12:111-116.

Chatzicharissis, I., K. Kazantzis, T. Sotiropoulos, and N. Koutinas. 2011. 'Bakirtzeika': A Greek sweet cherry cultivar. HortScience 46:10521053.

Christensen, J.V. 1984. Evaluation of qualitative characteristics of 48 sweet cherry cultivars. Danish J. Plant Soil Sci. 88:277-285.

Ganopoulos, I., A. Argiriou, and A. Tsaftaris. 2011. Microsatellite high resolution melting (SSRHRM) analysis for authenticity testing of protected designation of origin (PDO) sweet cherry products. Food Control 22:532-541.

Kafkaletou, M., M. Christopoulos, M. Ktistaki, T. Sotiropoulos, and E. Tsantili. 2015. Influence of rain cover on respiration, quality attributes and storage of cherries (Prunus avium L.). J. Appl. Bot. Food Qual. 88:87-96.

Sonneveld, T., K.R. Tobutt, and T.P. Robbins. 2003. Allele-specific PCR detection of sweet cherry self-incompatibility (S) alleles $S 1$ to $S 16$ using consensus and allele-specific primers. Theor. Appl. Genet. 107:1059-1070. 